\title{
THE ECONOMIC CRISIS AND
}

ASEAN STATES' SECURITY

Sheldon W. Simon

October 23, 1998 